\title{
sciendo
}

\author{
Current Issues in Pharmacy and Medical Sciences
}

Formerly ANNALES UNIVERSITATIS MARIAE CURIE-SKIODOWSKA, SECTIO DDD, PHARMACIA

journal homepage: http://www.curipms.umlub.pl/

\section{Genotoxicity of chromium (III) and cobalt (II) and interactions between them}

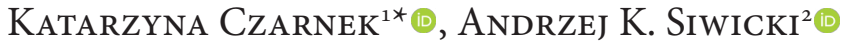 \\ ${ }^{1}$ Institute of Health Sciences, Faculty of Science and Health Sciences in Lublin, The John Paul II Catholic University of Lublin, Poland \\ ${ }^{2}$ Department of Microbiology and Clinical Immunology, Faculty of Veterinary Medicine, University of Warmia and Mazury in Olsztyn, \\ Olsztyn, Poland
}

\begin{tabular}{l}
\hline ARTICLE INFO \\
\hline Received 13 April 2021 \\
Accepted 20 June 2021
\end{tabular}

\section{Keywords:}

cobalt,

chromium,

genotoxicity,

interactions.

\begin{abstract}
Introduction. Chromium and cobalt are essential trace elements that are required only in a small amount, otherwise their excess can cause toxic effects.

Aim. The aim of this study was to determine the effects of chromium (III) and cobalt (II) and their combinations on genotoxicity in human fibroblasts cells (BJ).

Material and methods. In this work, comet and micronucleus assays were used. The BJ cells were exposed to chromium chloride and cobalt chloride at concentration ranges from 100 to $1400 \mu \mathrm{M}$. Mixtures of these elements were prepared so as to examine interactions between them.

Results. The present study shows the genotoxic effects of chromium (III) and cobalt (II) and their mixtures on BJ cells. In the comet assay, no comets were observed at the lowest concentrations; in the higher, a significant increase in their percentage was observed. In the other assay (formation of micronuclei), a statistically significant increase in the number of cells with micronuclei was observed in the BJ cells spiked with cobalt chloride and chromium chloride. In the case of simultaneous incubation of chromium chloride at $200 \mu \mathrm{M}$ and cobalt chloride at $1000 \mu \mathrm{M}$ in the BJ line, antagonism was observed. However, the interaction of chromium chloride at the $1000 \mu \mathrm{M}$ and cobalt chloride at $200 \mu \mathrm{M}$ leads to synergism between the studied elements.

Conclusions. Cobalt (II) and chromium (III) show genotoxic properties, they induce breaks in double and single-stranded DNA and they cause formation of AP-sites that do not have purine or pyrimidine bases.
\end{abstract}

\section{INTRODUCTION}

Chromium and cobalt are trace elements that play very important roles in the biological system. Cobalt (II) is a precursor of vitamin B12, which affects the proper functioning of the nervous system. Chromium (III) is necessary for several biochemical processes, it is beneficial for proper carbohydrate lipid and protein metabolism [1-3]. These trace elements are necessary only in small amounts. In high concentrations they can be potentially toxic to cells and they can induce a number of morphological and biochemical changes leading to cell death by apoptosis [2].

Exposure to chromium and cobalt is widespread. Both metals are used in numerous applications in industry and can cause environmental pollution. These metals are also

\footnotetext{
* Corresponding author

e-mail: kczarnek@kul.pl
}

ingredients of supplements, vitamins and energy drinks. Additionally, cobalt and chromium are components of biomaterials used in implants which can corrode in the environment of tissue fluids, and the metal ions that are released in this way can be stored for a long time and can become toxic to the organism. Accumulation of these metals in the body can lead to significant morphological and biochemical changes in cells. Accumulation of cobalt (II) in the cell can lead to interactions between the metal and DNA and nuclear proteins [1].

Cobalt (II) induces DNA double breaks, mutations in genes, aneuploid formation and small apoptotic bodies associated with DNA fragmentation [4-7]. What is more, cobalt disrupts the normal course of the cell cycle - in the metaphase it induces the formation of numerous aberrations within the chromatids [8]. Moreover, cobalt can cause an increase of protein kinase (MAP) and its phosphorylation. In 
addition, it elevates p53 protein levels, and, consequently, it affects hypoxia-inducible factor-1 (HIF-1) activation, which leads to apoptosis. Beyond the aforementioned, cobalt (II) destabilizes the proper functioning of enzymes belonging to the antioxidant system, such as superoxide dismutase (SOD), catalase (CAT) and glutathione peroxidase (GPx) [1].

Chromium (III) is also a toxic element. The literature data clearly indicate that high concentrations of chromium (III), as well as its compounds, have a destructive effect on DNA causing its fragmentation, the formation of micronuclei, induction of chromosome aberrations and exchange of sister chromatids [9-11]. Moreover, this element can bind to DNA and interfere with the replication process (at lower concentrations) or block it completely (at higher concentrations) [9]. Chromium (III) compounds can also bind directly to DNA in vitro forming Cr-DNA complexes and they form cross-links between DNA-DNA [12].

Both metals: cobalt (II) and chromium (III) are able to generate ROS. These reactive forms become a very destructive effect on the antioxidant system, which is unable to remove harmful forms of oxygen under conditions of imbalance in the cell [13-16]. These metals induce oxidation and nitrification of proteins - which lead to cell death [17].

In our investigation, genotoxic effects of cobalt and chromium and their combinations in the BJ cell line were studied.

\section{MATERIALS AND METHODS}

\section{Reagents}

Chromium chloride $\left(\mathrm{CrCl}_{3} \times 6 \mathrm{H}_{2} \mathrm{O}\right)$ and cobalt chloride $\left(\mathrm{CoCl}_{2} \times 6 \mathrm{H}_{2} \mathrm{O}\right)$ were purchased from Across Organics (Geel, Belgium); Eagle's Minimum Essentials Medium (EMEM) and fetal bovine serum (FBS) were obtained from ATCC; antibiotic antimycotic solution $(10.000 \mathrm{U} / \mathrm{ml}$ of penicillin, $10 \mathrm{mg} / \mathrm{mL}$ of streptomycin, $25 \mu \mathrm{g} / \mathrm{mL}$ of amphotericin $\mathrm{B})$, acridine orange and cytochalasin B were purchased from Sigma Chemical Co., (St. Louis, MO, USA). The Oxi select 96-well comet assay kit we utilized was acquired from Cell Biolabs, Imc., San Diego, CA, USA.

The research was carried out on human fibroblast BJ cell lines obtained from American Type Culture Collection (CRL-2522). The cells were grown as adherent monolayers in plastic tissue culture dishes in Eagle's Minimum Essentials Medium (EMEM) which was supplemented with 10\% fetal bovine serum (FBS) and antibiotic antimycotic solution (10,000 U/ml of penicillin, $10 \mathrm{mg} / \mathrm{mL}$ of streptomycin, $25 \mu \mathrm{g} / \mathrm{mL}$ of amphotericin B) at $37^{\circ} \mathrm{C}$ and $5 \% \mathrm{CO}_{2}$.

Chromium chloride $\left(\mathrm{CrCl}_{3} \times 6 \mathrm{H}_{2} \mathrm{O}\right)$ and cobalt chloride $\left(\mathrm{CoCl}_{2} \times 6 \mathrm{H}_{2} \mathrm{O}\right)$ were dissolved in PBS at the concentration of $1 \mathrm{mM}$. Solutions of chromium chloride or cobalt chloride at concentration range from 100 to $1400 \mu \mathrm{M}$ were then prepared by dilution in culture medium EMEM, supplemented with FBS and antibiotics. In the genotoxicity assays, the BJ cell line was exposed to chromium chloride and cobalt chloride at concentrations ranges from 100 to $1400 \mathrm{uM}$.

\section{Genotoxicity assays}

In this work, comet and micronucleus assays were used. The cells were cultured in 96-well plates $\left(2 \times 10^{5}\right.$ cells $\left./ \mathrm{mL}\right)$ in $100 \mu \mathrm{L}$, in complete growth medium (EMEM supplemented with $10 \%$ FBS and mixture of antibiotics). After a 24 hour incubation of the fibroblasts, the culture fluid was exchanged into a new one in the control case or was supplemented with chromium chloride or cobalt chloride at concentration ranges from 100 to $1400 \mu \mathrm{M}$. In order to determine the interactions between the above-mentioned microelements, the cells were similarly plated and incubated for 24 hours. Next, the culture fluid was exchanged for a fresh one and supplemented with mixture compounds of the following combinations: $200 \mu \mathrm{M}$ chromium chloride and 1000 $\mu \mathrm{M}$ cobalt chloride $(\mathrm{Cr} 200+\mathrm{Co} 1000)$ or $1000 \mu \mathrm{M}$ chromium chloride and $200 \mu \mathrm{M}$ cobalt chloride (Cr1000+Co200).

\section{The comet assay}

The comet assay is a common technique for measurement of DNA damage in individual cells. This assay detects breaks in DNA. Nucleic acid fragments subjected to electrophoresis move outside the nucleus forming a comet-like tail [18]. This assay was performed according to the original manufacture's instructions - Oxi Select 96-Well Comet Assay Kit, from Cell Biolabs, INC.

The prepared plates were subjected to microscopic observation using a FITC filter. A hundred cells were selected of each concentration and then the cells with damaged DNA (the so-called ones with a comet tail) were photographed using a Leica DM IL LED FLUO inverted microscope and assessed by means of the image analysis program Leica Application Suite 4.4. The experiment was performed in 6 independent replications.

\section{The micronucleus assay}

This assay is applied for detecting chromosome breaks and division spindle defects. Micronuclei are formed from the acentric chromatids, chromosome fragments, or from whole chromosomes. These fragments after telephosis are not incorporated into the nuclei of progenitor cells and they form micronuclei in the cytoplasm [19]. The micronucleus test was performed in accordance with OECD Guideline 487: In Vitro Mammalian Cell Micronucleus Test and PN-EN ISO 10993-3:2008 standard. After 24 hours of incubation of the cells with the test compounds or their mixtures, cytochalasin B was added. After this time, the culture fluid was decanted from the plates and the dye, acridine orange, was added at the final concentration of $100 \mu \mathrm{g} / \mathrm{ml}$. Microscopic observations were then made using the appropriate FITC filter, and photographic documentation was made by means of a Leica DM IL LED FLUO inverted microscope, using the image analysis software Leica Application Suite 4.4. Results were reported by analyzing the binucleated micronucleated cell frequency as a number of binucleated cells containing one or more micronuclei per 1,000 binucleated cells. The experiment was performed in 6 independent replications. 


\section{Statistics}

The results were assessed by applying one-way analysis of variance (ANOVA), with Tukey's multiple comparisons, using Statistica version 4.0. In all cases, $\mathrm{p}<0.05$ was considered significant.

\section{RESULTS}

This study shows that both cobalt and chromium exhibit genotoxic properties by causing DNA and chromosome breaks and damage of the division spindle. Both tested compounds induced damage of DNA in the BJ cell line. Moreover, there was a statistically significant increase in the percentage of comets with increasing concentration of the tested compound compared to the control. Table 1 shows the results obtained in the comet assay after treatment of the BJ cell line with cobalt chloride or chromium chloride. In the micronucleus assay, statistically significant induction of chromosomal aberrations in the above-mentioned compounds was observed.

Table 1. Percentage of DNA tail after incubation with chromium chloride or cobalt chloride and their mixtures in the BJ cell line, detected with the comet assay

\begin{tabular}{|c|c|c|}
\hline \multicolumn{2}{|c|}{ Concentration of $\mathrm{CrCl}_{3} \times 6 \mathrm{H}_{2} \mathrm{O}[\mu \mathrm{M}]$} & Percentage of tail DNA \\
\hline \multicolumn{2}{|c|}{0} & 0 \\
\hline \multicolumn{2}{|c|}{100} & 0 \\
\hline \multicolumn{2}{|c|}{200} & $2 \pm 0.19$ \\
\hline \multicolumn{2}{|c|}{400} & $3 \pm 0.28 *$ \\
\hline \multicolumn{2}{|c|}{600} & $6 \pm 0.58 *$ \\
\hline \multicolumn{2}{|c|}{800} & $6 \pm 0.54 *$ \\
\hline \multicolumn{2}{|c|}{1000} & $8 \pm 0.7^{*}$ \\
\hline \multicolumn{2}{|c|}{1200} & $12 \pm 1 *$ \\
\hline \multicolumn{2}{|c|}{1400} & $13 \pm 1 *$ \\
\hline \multicolumn{2}{|c|}{ Concentration of $\mathrm{CoCl}_{2} \times 6 \mathrm{H}_{2} \mathrm{O}[\mu \mathrm{M}]$} & Percentage of tail DNA \\
\hline \multicolumn{2}{|c|}{0} & 0 \\
\hline \multicolumn{2}{|c|}{100} & 0 \\
\hline \multicolumn{2}{|c|}{200} & 0 \\
\hline \multicolumn{2}{|c|}{400} & $3 \pm 0.21$ \\
\hline \multicolumn{2}{|c|}{600} & $7 \pm 0.62 *$ \\
\hline \multicolumn{2}{|c|}{800} & $70 \pm 6.2 *$ \\
\hline \multicolumn{2}{|c|}{1000} & $88 \pm 7.2 *$ \\
\hline \multicolumn{2}{|c|}{1200} & $96 \pm 8.3^{*}$ \\
\hline \multicolumn{2}{|c|}{1400} & $100 \pm 9 *$ \\
\hline \multicolumn{2}{|c|}{ Concentration (mixture of metal compounds) } & Percentage of tail DNA \\
\hline $200 \mu \mathrm{M}$ & $1000 \mu \mathrm{M}$ & \\
\hline $\mathrm{CrCl}_{3} \times 6 \mathrm{H}_{2} \mathrm{O}$ & $\mathrm{CoCl}_{2} \times 6 \mathrm{H}_{2} \mathrm{O}$ & $12 \pm 0.9 * 1,2$ \\
\hline $1000 \mu \mathrm{M}$ & $200 \mu \mathrm{M}$ & \\
\hline $\mathrm{CrCl}_{3} \times 6 \mathrm{H}_{2} \mathrm{O}$ & $\mathrm{CoCl}_{2} \times 6 \mathrm{H}_{2} \mathrm{O}$ & $9 \pm 0.8^{*}$ \\
\hline
\end{tabular}

* significance of difference compared with control $p \leq 0.05 ;{ }^{1}$ significance of difference compared with chromium chloride at concentration $200 \mu \mathrm{M}$, $\mathrm{p} \leq 0.05 ;^{2}$ significance of difference compared with cobalt chloride at concentration $1000 \mu \mathrm{M}, \mathrm{p} \leq 0.05$

A statistically significant increase in the number of micronucleated cells was observed with an increase of the concentration of the tested compound, as compared to the control cells of the BJ lines. While the BJ cell line was exposed to higher concentrations, such as 1200 and $1400 \mu \mathrm{M}$ of the tested compound, polynucleated and giant cells with vacuolated cytoplasm and altered membrane in the form of vesicles on its surface were observed. These changes indicate apoptosis. Table 2 shows the results obtained in the micronucleus assay in the BJ cell line after treatment with cobalt chloride or chromium chloride and their mixtures.

Table 2. Frequency of micronucleated binucleated cells induced by chromium chloride or cobalt chloride and their mixtures in the $\mathrm{BJ}$ cell line - as detected with the micronucleus assay

\begin{tabular}{|c|c|c|}
\hline \multicolumn{2}{|c|}{ Concentration of $\mathrm{CrCl}_{3} \times 6 \mathrm{H}_{2} \mathrm{O}[\mu \mathrm{M}]$} & BNMN\%o \\
\hline \multicolumn{2}{|c|}{0} & 0 \\
\hline \multicolumn{2}{|c|}{100} & 0 \\
\hline \multicolumn{2}{|c|}{200} & 2 \\
\hline \multicolumn{2}{|c|}{400} & $8 \pm 0.7 *$ \\
\hline \multicolumn{2}{|c|}{600} & $13 \pm 0.88 *$ \\
\hline \multicolumn{2}{|c|}{800} & $15 \pm 0.98 *$ \\
\hline \multicolumn{2}{|c|}{1000} & $24 \pm 1.8^{*}$ \\
\hline \multicolumn{2}{|c|}{1200} & apoptosis \\
\hline \multicolumn{2}{|c|}{1400} & apoptosis \\
\hline \multicolumn{3}{|c|}{ Concentration of $\mathrm{CoCl}_{2} \times 6 \mathrm{H}_{2} \mathrm{O}[\mu \mathrm{M}]$} \\
\hline \multicolumn{2}{|c|}{$\mathbf{0}$} & 0 \\
\hline \multicolumn{2}{|c|}{100} & 1 \\
\hline \multicolumn{2}{|c|}{200} & $4 \pm 0.35 * a$ \\
\hline \multicolumn{2}{|c|}{400} & $4 \pm 0.4 * a$ \\
\hline \multicolumn{2}{|c|}{600} & apoptosis \\
\hline \multicolumn{2}{|c|}{800} & apoptosis \\
\hline \multicolumn{2}{|c|}{1000} & apoptosis \\
\hline \multicolumn{2}{|c|}{1200} & apoptosis \\
\hline \multicolumn{2}{|c|}{1400} & apoptosis \\
\hline \multicolumn{2}{|c|}{ Concentration (mixture of metal compounds) } & BNMN\% \% \\
\hline $200 \mu \mathrm{M}$ & $1000 \mu \mathrm{M}$ & \\
\hline $\mathrm{CrCl}_{3} \times 6 \mathrm{H}_{2} \mathrm{O}$ & $\mathrm{CoCl}_{2} \times 6 \mathrm{H}_{2} \mathrm{O}$ & $24 \pm 1.8^{* 1,2}$ \\
\hline $1000 \mu \mathrm{M}$ & $200 \mu \mathrm{M}$ & \\
\hline $\mathrm{CrCl}_{3} \times 6 \mathrm{H}_{2} \mathrm{O}$ & $\mathrm{CoCl}_{2} \times 6 \mathrm{H}_{2} \mathrm{O}$ & $32 \pm 2.5 * 3,4$ \\
\hline
\end{tabular}

* significance of difference compared with control $p \leq 0.05$; a 1000 cells were not counted; ${ }^{1}$ significance of difference compared with chromium chloride at concentration $200 \mu \mathrm{M}, \mathrm{p} \leq 0.05 ;^{2}$ significance of difference compared with cobalt chloride at concentration $1000 \mu \mathrm{M}, \mathrm{p} \leq 0.05 ;{ }^{3}$ significance of difference compared with chromium chloride at concentration $1000 \mu \mathrm{M}$, $\mathrm{p} \leq 0.05 ;{ }^{4}$ significance of difference compared with cobalt chloride at
, concentration $200 \mu \mathrm{M}, \mathrm{p} \leq 0.05$

A statistically significant decrease in the percentage of comets during simultaneous incubation in chromium chloride at $200 \mu \mathrm{M}$ and cobalt chloride at $1000 \mu \mathrm{M}$ in the BJ line was observed, when compared to cells incubated only with $1000 \mu \mathrm{M}$ cobalt chloride. We also noted a small statistically significant increase in the percentage of comets as compared to cells incubated only with chromium chloride at the concentration of $200 \mu \mathrm{M}$. Tables 1 and 2 show the genotoxic effects of the tested mixtures. However, in the case of interaction of chromium chloride at the concentration $1000 \mu \mathrm{M}$ and cobalt chloride at $200 \mu \mathrm{M}$, simultaneous incubation of the BJ cell line caused an increase in the percentage of comets in the cells, as compared to the percentage of comets observed in cells incubated only with cobalt 
chloride at the concentration of $200 \mu \mathrm{M}$. When compared to those incubated only with $1000 \mu \mathrm{M}$ chromium chloride, no significant differences were observed in the percentage of comets formed in the cells.

In the micronucleus assay, in the case of interaction of $\mathrm{Cr} 200+\mathrm{Co} 1000$, incubation of the BJ line increased the number of cells with micronuclei when compared to the cells incubated with chromium chloride at the concentration of $200 \mu \mathrm{M}$. An increase in the number of normal cells compared to the cells incubated only with cobalt chloride at the concentration of $1000 \mu \mathrm{M}$ was also observed. In the case of simultaneous incubation of cells of the BJ cell line, a statistically significant increase in the number of cells with micronuclei was noted when compared to the cells incubated only with chromium chloride at the concentration of 1000 $\mu \mathrm{M}$ or cobalt chloride at the concentration of $200 \mu \mathrm{M}$.

\section{DISCUSSION}

A number of morphological, biochemical (such as destruction of proteins, lipids and deoxyribonucleic acid) and functional changes of cell leading to disturbances of its metabolism and even death by apoptosis occurred in cells under the influence of cobalt (II) and chromium (III). These changes are the result of the toxic action of these metals $[7,10,11,20]$. The carried-out studies showed that cobalt (II) and chromium (III) induced genotoxic effects in the BJ cell line. The concentrations of chromium chloride or cobalt chloride in these studies were chosen on the basis of other reports. In this study, in the comet assay, after incubation of the BJ cell line with cobalt chloride at the lowest concentrations, no comets were observed. However, a slight increase in their percentage was observed at the concentrations of $400 \mu \mathrm{M}$ and $600 \mu \mathrm{M}$, and a large increase at the concentrations from 800 to $1400 \mu \mathrm{M}$. These results indicate that cobalt chloride causes breaks in single- and double-stranded DNA and AP - (no purine or pyrimidine bases) sites. The results received in this study were confirmed by earlier studies conducted on $\mathrm{H} 460$ cell lines, $\mathrm{HaCaT}$ keratinocytes, human lung fibroblasts WTHBF-6, astrocytes C57B16 and mouse macrophages J774, where exposure to cobalt (II) ions induced the formation of double breaks in DNA and the formation of small apoptotic bodies associated with DNA fragmentation. Moreover, features of late apoptosis with visibly altered cell membrane with apoptotic bodies as well as necrosis visible as extensive cell membrane damage were observed $[4,13,21-23]$.

The genotoxic effect of the metal was also confirmed in the micronucleus test (which detects chromosome breaks and damage to the spindle). In this investigation, giant, multinucleated cells with vacuolated cytoplasm and altered cell membrane in the form of vesicles on its surface were observed in the BJ cell line. These results were confirmed by other studies, which reported that MG-63 osteoblasts, when treated with cobalt (II) ions, have significantly increased size, and the large spaces visible in the microscopic image indicate a significant decrease in cell number [5]. The available literature data clearly indicate that exposure to cobalt (II) compounds causes DNA breaks, formation of cross-links between proteins and DNA, exchange of sister chromatids and formation of micronuclei in mammalian cells $[6,24]$. In the present study, in the micronucleus assay, apoptosis was observed in concentrations above $600 \mu \mathrm{M}$. The genotoxic effect of the metal was confirmed by other authors who had conducted similar studies on the effect of cobalt chloride on astrocytes, which showed the characteristics of apoptotic cells. Herein, phosphatidylserine was found to move from the internal layer to the external cytoplasmic membrane, which is the typical phenomenon of cell death by apoptosis [1].

Cobalt (II) is mainly accumulated in the cell nucleus, in smaller amounts in the cytosol and in perinuclear structures (such as the endoplasmic reticulum and the Golgi apparatus) [25]. Cobalt (II) induces oxidation and nitrification of cellular proteins which lead to apoptosis [17]. The genotoxicity effects of cobalt may be related to its ability to generate ROS, which are very destructive to DNA. Moreover, cobalt (II) can inhibit the antioxidative activity of enzymes [23], and cobalt (II) ions can cause increased levels of damage in vitro in the presence of hydrogen peroxide or UV radiation $[6,26]$. Beyond the aforementioned, cobalt (II) can cause DNA fragmentation, as well as the activation of the caspase system (the outcome of reaction with hydrogen peroxide in the Fenton reaction). The resulting free radicals can cause cell destruction, and the degree of their formation depends on the functioning of the defense system, especially the enzymes: superoxide dismutase, catalase, and glutathione reductase $[1,27,28]$. The reduction in SOD enzyme activity is associated with the binding of cobalt(II) to the zinc and copper sites in SOD, thereby reducing the enzyme activity [26].

Similar observations were made in other studies in which the osteoblast line was treated with cobalt (II) ions. Changes in SOD enzyme activity dependant on the time of element exposure were noted. A decrease of $11 \%$ was observed after 24 hours, and $36 \%$ after 72 hours. For the HO -1 enzyme, there was a maximum stimulation of its activity during the first 24 hours (6-fold higher compared to the control), and a gradual decrease in its activity over this time. Furthermore, cobalt (II) stimulated an increase in GPx activity [20]. The element can bind with sulfhydryl groups of proteins and enzymes and interfere with the proper metabolism of glutathione - an essential antioxidant that plays a key role in metabolism and excretion of xenobiotics. What is more, it binds stoichiometrically at the zinc and copper sites in SOD, thereby reducing the activity of the enzyme $[29,30]$. Cobalt (II) may affect DNA repair mechanisms through interactions with magnesium and zinc ions in specific enzymes. Inhibition of this process contributes to mutation formation $[6,22]$. Baldwin et al. suggest that the genotoxic effects induced by cobalt (II) may also be mainly related to the inhibition of topisomerase II $\alpha$ activity in animal cells. Cobalt (II) interferes with the proper function of topoisomerase II (which requires divalent cations to perform DNA cleavage reactions) by forming complexes with this enzyme [6]. Moreover, literature data report that cobalt (II) competes with zinc ions by which it may affect the efficiency of the mechanism of $\mathrm{p} 53$ protein binding to DNA, which is dependent on the presence of these ions $[31,32]$. 
The experiments carried out in this study also confirmed the genotoxic effect of chromium chloride. Chromium (III) binds most strongly of all metals to nucleic acids, thus affecting the expression of genetic information [2,33]. Additionally, chromium(III) can bind to DNA, forming adducts and cross-links between DNA strands [12]. The mechanism is based on the reaction of $\mathrm{Cr}$ (III) ions with negatively charged phosphate groups or directly with guanine [34]. In the present study, in the comet assay, a statistically significant increase in comet in the BJ cell line with increasing chromium chloride concentrations was noted. These results are in agreement with the studies by other authors in which the BJ cell line was treated with chromium chloride, where the formation of chromosomal aberrations was observed in a dose-dependent manner [11]. Furthermore, other studies confirm that high concentrations of chromium (III), as well as its compounds (such as picolinate and chromium nicotinate), are capable of inducing chromosome aberrations, causing DNA fragmentation in J774A macrophages [9].

The destructive action of chromium chloride against DNA is manifested by the formation of breaks in double- and single-stranded DNA and AP sites that are lacking purines and pyrimidines [35]. These destructive changes are in agreement with the present investigation where the BJ cell line was treated in increasing concentrations of chromium chloride. In the next micronucleus formation assay, a statistically significant increase in the number of cells with micronuclei was observed for the BJ cell line. The results of micronucleus assay indicated changes in morphological and biochemical structures in fibroblasts above the concentration of $1000 \mu \mathrm{M}$. The microscopic observation carried out in this study allowed the observation of cells with signs of apoptosis, which indicated the destructive effect of chromium chloride on the BJ cells line studied. Apoptosis was noted in higher concentrations of chromium at the 1200 and 1400. Moreover, we observed giant, multinucleated cells with vacuolated cytoplasm and an altered membrane in the form of vesicles on its surface.

These results confirm previous studies in which chromium (III) complexes induced micronuclei formation in Chinese hamster ovary lung V79 cells and MCR fibroblasts $[9,36]$. In addition, similar observations were confirmed in previous studies where keratinocytes treated with chromium chloride or chromium picolinate exhibited characteristics of apoptotic cells, i.e. chromatin condensation and the presence of numerous vesicles on the cell membrane surface [16,37]. Studies by other authors indicate that chromium (III) compounds have the ability to generate reactive oxygen species, which have a destructive effect on DNA and mitochondria that leads to apoptosis. These genotoxic effects of chromium (III) were observed in AA8 Chinese hamster cells [10]. In addition, chromium (III) has a destructive effect on lipids, causing their peroxidation in liver and kidney cells.

One of the products of its action is the formation of malon dialdehyde (MDA) - a marker of oxidative stress DNA -8-hydroxy-deoxy-guanosine [14]. This marker is formed by the oxidation of guanine at position C8 in the DNA strand by a hydroxyl radical. The formation of such a compound leads to the conversion of guanine to thymine during replication, resulting in numerous mutations [14]. This element can bind to DNA and interfere with the replication process (in lower concentrations) or block it completely. The activity of SOD, GSH-Px enzymes gradually decreases under the influence of the increase of reactive oxygen species, which leads to irreversible destructive changes, i.e. lipid peroxidation and MDA formation [38].

Chromium is able to generate ROS, and in the presence of hydrogen peroxide in the Fenton reaction it can increase the level of damage. What is more, the metal inhibits the activity of the antioxidant system, which is unable to remove harmful forms of oxygen under conditions of imbalance in the cell. The activity of superoxide dismutase and glutathione peroxidase enzymes gradually decreases under the influence of ROS, which leads to irreversible destructive changes, such as lipid peroxidation and formation of malondialdehyde [13-16].In addition, other studies in which an osteoblast line was treated with cobalt (II) ions for a time interval of 24 to 72 hours reported changes in antioxidant enzyme activity. A gradual increase in CAT activity was observed, which reached 1.7-fold higher and GPx 1.9-fold higher compared to the control system after 72 hours of incubation of cells with the metal. In contrast, heme oxygenase enzyme showed a maximum stimulation of its activity during the first 24 hours (2-fold higher compared to controls), followed by a gradual decrease in activity over time [20].

On the basis of the results obtained from the first stage of the research, the concentrations of the elements were selected in order to determine the interactions between them. The investigations performed by Czarnek and Siwicki [39] show that both tested elements in the lowest concentrations do not cause changes in cell viability. Accordingly, cell viability was sometimes slightly stimulated, but at the concentration of $1000 \mu \mathrm{M}$ and above, a decrease of cell viability was observed. Despite many scientific reports, the metabolism of chromium (III) and cobalt (II) has not been fully understood and interactions between them are unknown. The interactions between the elements can be different - when we observed reduced effects, we noticed antagonism, and in the case of their intensification, synergism was observed.

The present study showed the results of the effects of chromium (III) and cobalt (II) in the following combinations $(\mathrm{Cr} 200+\mathrm{Co} 1000)$ and $(\mathrm{Cr} 1000+\mathrm{Co} 200)$. During simultaneous incubation with chromium chloride at $200 \mu \mathrm{M}$ and cobalt chloride at $1000 \mu \mathrm{M}$, in the comet assay, a decrease in the percentage of comets was noted - chromium (III) at the concentration of $200 \mu \mathrm{M}$ had a protective function against the toxic concentration of cobalt (II) at $1000 \mu \mathrm{M}$. In this interaction, antagonism was observed. In the micronucleus formation assay, an increase in the number of normal cells was observed, which is synonymous with the protective effect of chromium (III) at the concentration of $200 \mu \mathrm{M}$ in this interaction. This protective effect of chromium results from an increase in activity of antioxidant system enzymes in low concentration of chromium chloride. These observations are an agreement with the results of the previous research conducted by Chen et al., in which enzymes of the antioxidant system (in a non-cellular system) were treated with chromium (III) in the range of 0 to $5.0 \times 10^{-4} \mathrm{~mol} \mathrm{l}^{-1}$. In low concentrations, i.e. $2.0 \times 10^{-4} \mathrm{~mol} \mathrm{l}^{-1}$, chromium 
chloride was observed to increase catalase activity, which decreased at higher concentrations. The destructive effect was due to the destruction of the active center of this enzyme by chromium (III) [40]. The ability of low concentrations of chromium (III) to stimulate catalase activity results in its protective effect against the post-oxidative effect of cobalt (II) used in high concentrations. In the interaction of chromium chloride at $1000 \mu \mathrm{M}$ and cobalt chloride at $200 \mu \mathrm{M}$, no protective activity of chromium chloride in the presence of cobalt chloride was observed. In this case, synergism between the tested elements was observed. In the genotoxicity assay, an increase in the percentage of comets, but a decrease in the number of normal cells was noted. The lack of protective effect of chromium chloride at $1000 \mu \mathrm{M}$ is associated with the generation of ROS and a decrease in the efficiency of the activity of antioxidant system enzymes [40]. In this case, chromium (III) at $1000 \mu \mathrm{M}$ enhances the proapoptotic effect of cobalt chloride at $200 \mu \mathrm{M}$.

\section{CONCLUSION}

Summing up, cobalt and chromium are genotoxic metals. The genotoxicity of the metals is related to the ability of both metals to generate reactive oxygen species that are highly destructive to DNA and mitochondrion. This leads to apoptosis. Under conditions of imbalance, the antioxidant system is not efficient enough to counteract in such situations and the enzymes of the antioxidant system may be damaged. Cobalt (II) and chromium (III) show genotoxic properties, induce breaks in double and single-stranded DNA and the formation of AP-sites that do not have purine or pyrimidine bases in the BJ cell line. In our work, we saw a statistically significant increase in the percentage of comets with increasing concentration of the tested compound, compared to the control. In the micronucleus assay, statistically significant induction of chromosomal aberrations in the above mentioned compounds was also observed. In the simultaneous incubation with chromium chloride at $200 \mu \mathrm{M}$ and cobalt chloride at $1000 \mu \mathrm{M}$, antagonism was noted: chromium (III) at the concentration of $200 \mu \mathrm{M}$ had a protective function against the toxic concentration of cobalt (II) at $1000 \mu \mathrm{M}$. However, in the interaction of chromium chloride at 1000 $\mu \mathrm{M}$ and cobalt chloride at $200 \mu \mathrm{M}$, no protective activity of chromium chloride in the presence of cobalt chloride was observed. In this case, synergism between the tested elements was apparent.

\section{ORCID iDs}

Katarzyna Czarnek (1)https://orcid.org/0000-0002-7081-5526 Andrzej K. Siwicki (1) https://orcid.org/0000-0002-7372-2181

\section{REFERNCES}

1. Karovic O, Tonazzini I, Robola N, Edstrom E, Lovdahl C, Fredholm BB. Toxic effects of cobalt in primary cultures of mouse astrocytes. Similarities with hypoxia and role of HIF-1a. Biochem Pharmacol. 2007;73:694-708.

2. Pechova A, Pavlata P. Chromium as an essential nutrient: a review. Vet Med. 2007;52(1):1-18.

3. Vincent JB. New evidence against chromium as an essential trace element. J Nutr. 2010;147(12):2212-9.

4. Bresson C, Lamouroux C, Sandre C, Tabarant M, Gault N, Poncy JL, et al. An interdisciplinary approach to investigate the impact of cobalt in a human keratinocyte cell line. Biochimie. 2008;88:1619-29.

5. Catelas I, Petit A, Valic H, Fragiskatosd C, Meilleurd R, Zukorb DJ, et al. Quantitative analysis of macrophage apoptosis vs. necrosis induced by cobalt and chromium ions in vitro. Biomaterial. 2005;26:2441-53.

6. Gault N, Sandre C, Poncy J-L, Moulin C, Lefaix J-L, Bresson C. Cobalt toxicity: chemical and radiological combined effects on HaCaT keratinocyte cell line. Toxicol Vitro. 2010;24:92-8.

7. Pulido MD, Parrish AR. Metal - induced apoptosis: mechanisms. Mutat Res. 2003;2003:227-41.

8. Pouget JP, Mather SJ. General aspects of cellular response to low and hight-LET radiation. Eur J Nucl Med. 2001;28:541-61.

9. Eastmond DA, MacGregor JT, Slesinski RS. Trivalent chromium: Assessing the genotoxic risk of an essential trace element and widely used human and animals nutrtional suplement. Crit Rev Toxicol. 2008;38:173-90.

10. Staniek H, Kostrzewska-Poczekaj M, Arndt M, Szyfterb K, Krejpcio Z. Genotoxicity assessment of chromium (III) propionate complex in the rat model using the comet assay. Food Chem Toxicol. 2010;48:89-92.

11. Figgitt M, Newson N, Lesliec IJ, Fisher J, Ingham E, Case ChP. The genotoxicity of physiological concentrations of chromium $(\mathrm{Cr}$ (III) and Cr (VI)) and cobalt (Co (II)): An in vitro study. Mutat Res. 2010;688:53-61.

12. O'Brien TJ, Ceryak S, Patierno SR. Complexities of chromium carcinogenesis: role of cellular response repair and recovery mechanisms. Mutat Res. 2003;533:3-36.

13. Galanis A, Karapetsas A, Sandaltzopoulos R. Metal-induced carcinogenesis, oxidative stress and hypoxia signaling. Mutat Res Fund Mol Mech Mutagen. 2009;674:31-5.

14. Hepburn DDD, Vincent JB. Tissue and subcellular distribution of chromium picolinate with time after entering the bloodstream. J Inorg Biochem. 2003;94:86-93.

15. Petit A, Mwale F, Tkaczyk C, Antoniou J, Zukor DJ, Huk OL. Induction of protein oxidation by cobalt and chromium ions in human U937 macrophages. Biomaterials. 2005;26:4416-22.

16. Shrivastava HY, Ravikumar T, Shanmugasundaram N, Babu M, Nair BU. Cytotoxicity studiem of chromiu (III) complexes on human dermal fibroblasts. Free Radic Biol Med. 2005;38:58-69.

17. Tkaczyk C, Huk OL, Mwale F, Antoniou J, Zukor DJ, Petit A. The molecular structure of complexes formed by chromium or cobalt ions in simulated physiological fluids. Biomaterials. 2009;30:460-7.

18. Stokłosowa S. Hodowla komórek i tkanek. Warszawa: Wydawnictwo Naukowe PWN;2011.

19. Traczewska TM. Biologiczne metody oceny skażenia środowiska. Wrocław: Oficyna Wydawnicza Politechniki Wrocławskiej;2011.

20. Fleury C, Petita A, Mwalea A, Antonioua J, Zukora DJ, Tabrizianb M, et al. Effect of cobalt and chromium ions on human MG-63 osteoblasts in vitro: Morphology, cytotoxicity, and oxidative stress. Biomaterials. 2006;27:3351-60.

21. Ermolli M, Menné Ch, Pozzi G, Serra MA, Clerici LA. Nickel, cobalt and chromium-induced cytotoxicity and intracellular accumulation in human hacat keratinocytes. Toxicology. 2001;159:23-31.

22. Ortega R, Bresson C, Fraysse A, Sandre C, Devec G, Gombert C, et al. Cobalt distribution in keratinocyte cells indicates nuclear and perinuclear accumulation and interaction with magnesium and zinc homeostasis. Toxicol Lett. 2009;188:26-32. 
23. Smith LJ, Holmes AL, Kandpal SK, Mason MD, Zheng T, Wise SP. The cytotoxicity and genotoxicity of soluble and particulate cobalt in human lung fibroblast cells. Toxicol Appl Pharmacol. 2014;278:259-65.

24. Ebert B, Jelkmann W. Intolerability of cobalt salt as erythropoietic agent. Drug Test Anal. 2014;6:185-9.

25. Papageorgiou I, Shadricka V, Davis S, Hails L, Schins R, Newson $\mathrm{RJ}$, et al. Macrophages detoxify the genotoxic and cytotoxic effects of surgical cobalt chrome alloy particles but not quartz particles on human cells in vitro. Mutat Res Fund Mol Mech Mutagen. 2008;643:11-9.

26. Lyons TJ, Nersissian A, Huang H, Yeom H, Nishida CR, Graden JA, et al. The metal binding properties of the zinc site of yeast copperzinc superoxide dismutase: implications for amyotrophic lateral sclerosis. JBIC. 2000;5:198-203.

27. Battaglia V, Compagnone A, Bandino A, Bragadin M, Rosii CA, Zanetti F, et al. Cobalt induces oxidative stress in isolated liver mitochondria responsible for permeability transition and intrinsic apoptosis in hepatocyte primary cultures. Int J Biochem Cell Biol. 2009;41:586-94.

28. Christova TY, Gorneva GA, Taxirov SI, Duridanova B, Setchenska MS. Effect of cisplatin and cobalt chloride on antioxidant enzymes in the livers of Lewis lung carcinoma - Bering mice: protective role of heme oxygenase. Toxicol Lett. 2003;138:235-42.

29. Hultberg B, Andersson A, Isaksson A. Interactions of metals and thiols in cell damage and glutatione distribution: potential of Merkury toxicity by dithiothreitol. Toxicology. 2001;56:93-100.

30. Garoui EM, Fetoui H, Makni FA, Boudawara T, Zeghal N. Cobalt chloride induces hepatotoxicity in adult rats and their suckling pups. Exp Toxicol Pathol. 2011;63:9-11.

31. Méplan C, Richard MJ, Hainaut P. Metalloregulation of the tumor suppressor protein $\mathrm{p} 53$ : zinc mediates the renaturation of $\mathrm{p} 53$ after exposure to metal chelators in vitro and in intact cells. Oncogene. 2000;19(46) 5227-36.
32. Palecek E, Brazdova M, Cernocka H, Vlk D, Brazda V, Vojtesek B. Effect of transition metals on binding of p53 protein to supercoiled DNA and to consensus sequence in DNA fragments. Oncogene. 1999;18(24):3617-25.

33. Rocha JFX, Aires AR, Nunes MG, Flores EMM, Kozloski GV, Vargas AC, et al. Metabolism, intake, and digestibility of lambs supplemented with organic chromium. Biol Trace Elem Res. 2013;156:130-3.

34. Snow ET. A possibile role for chromium (III) in genotoxicity. Environ Health Perspect. 1991;92:75-81.

35. Dai H, Liu J, Malkas LH, Catalano J, Algaharu S, Hickey RJ. Chromium reduces the in vitro activity and fidelity of DNA replication Mediatel by the human cell DNA replication mediated by the human cell DNA synhesome. Toxicol Appl Pharmacol. 2009;236:154-65.

36. Seoane AI, Dulout FN. Genotoxic ability of cadium, chromium and nickel salts studiem by kineto chore staining in the cytokinesis blocked micronucleus assay. Mutat Res. 2001;490:99-106.

37. Manygoats KR, Yazzie M, Stearns DM. Ultrastructural damage in chromium picolinate-treated cells: a TEM study. J Biol Inorg Chem. 2002;7:791-8.

38. Fan W-T, Zhao X-N, Cheng J, Liu Y-H, Liu J-Z. Oxidative stress and hepatocellular injury induced by oral administration of $\mathrm{Cr}^{3+}$ in chicken. J Biochem Mol Toxicol. 2015;29:6.

39. Czarnek K, Siwicki AK. Influence of chromium (III), cobalt (II) and their mixtures on cell metabolic activity. Curr Issues Pharm Med Sci. 2021;34(2):87-93.

40. Chen L, Zhang J, Zhu Y, Zhang Y. Interaction of chromium (III) or chromium (VI) with catalase and its effect on the structure and function of catalase: An in vitro study. Food Chem. 2018;244:378-85. 